\title{
The Role of a Pharmacist in Pharmacovigilance System
}

\author{
Marija M. Lučić ${ }^{1}$, Nastasija P. Milošević ${ }^{1}$, Nikola B. Martić1, \\ Milica M. Paut Kusturica ${ }^{1}$, Vojin M. Jovančević ${ }^{2}$, Milan B. Ubavić3 \\ Nemanja B. Todorović ${ }^{4}$, Dejan J. Krajačić ${ }^{5}$, Aleksandar L. Rašković ${ }^{1}$ \\ ${ }^{1}$ Department of Pharmacology and Toxicology, Faculty of Medicine Novi Sad, University of \\ Novi Sad, Novi Sad, Serbia \\ ${ }^{2}$ Provincial Secretariat for Education, Regulations, Administration and National Minorities, \\ Novi Sad, Serbia \\ ${ }^{3}$ Institute for Laboratory Diagnostics, Medlab, Novi Sad, Serbia \\ ${ }^{4}$ Department of Pharmacy, Faculty of Medicine Novi Sad, University of Novi Sad, Novi Sad, \\ Serbia \\ ${ }^{5}$ Genaral Hospital “Dr Radivoj Siminović” Sombor, Serbia
}

\section{SUMMARY}

Introduction: Although they represent an important mediator between patients and National Pharmacovigilance Centre, pharmacists still don't participate enough in system of reporting adverse drug reactions (ADR). By reporting ADR both quality of therapy and quality of patient's life are improving, and pharmaceutical industry is also encouraged to invent and produce new formulations which will be better beared and whose use will significantly improve risk-benefit ratio.

Aim: The aim of this work is that by collecting information about ADRs, based on direct contact of a pharmacist and patients, explain and improve the role of a pharmacist in pharmacovigilance system.

Subjects and Methods: Information about adverse reactions were being collected in three private pharmacies in Inđija and in one private pharmacy in Sombor. In period from 20.12.2017.-10.01.2018. pharmacists collected data about adverse reactions of medicines. In period from 11.01.-01.02.2018. patients were additionally informed about unexpected and adverse drug reactions. The standard form for reporting an adverse reaction, which was taken from the site of Medicines and Medical Devices Agency of Serbia (ALIMS), was filled for each reported case and sent to National Pharmacovigilance Center (NPC). Suspect drugs were classified in categories according to Anatomical-Therapeutic-Chemical classification (ATC).

Results: In first period, there were 19 reported reactions. After additional information given to patients, there were 33 reported adverse reactions. The most numerous adverse drug reactions were reported for the group of cardiovascular drugs (32.7\%), the group of anti-infective drugs with systemic effects (15.4\%) and for group of drugs which affect nervous system (13.5\%). After analyzing reported reactions, according to NPC all of reactions were expected (52), but 3 of them fulfilled criteria of seriousness.

Conclusions: Thanks to additional information and direct communication between a 
pharmacist and patients, reporting unexpected and adverse drug reactions is significantly improving.

Keywords: punexpected and adverse effects, pharmacovigilance

\section{INTRODUCTION}

No medicine is entirely safe. In other words, no medicine is risk free. Although many of the risks are known at the time of licensing a medicine, some information on its safety profile comes to light later, after marketing a medicine, as medicine usage increase. Before a medicine is marketed, information on its safety is limited to its use in clinical trials under specific, ideal circumstances that do not necessarily reflect the way the medicines are used in daily routine health practice, once they are marketed. Despite the extensive pre-marketing research, non-clinical trials in animals and clinical trials in humans, some adverse reactions may not be seen until a very large number of people have received the medicine. Therefore it is very important that the safety of all medicines is monitored throughout their marketed life - known as pharmacovigilance [1].

\section{Adverse drug reaction}

Adverse reaction to the drug (ADR) is every noxious and unintended reaction to the drug which occurs after the usage of an usual dose of the drug by people and animals (for the purpose of therapy, prophylaxis, diagnosis, renewal, improvement or change of a physiological function) or after the usage of any dose of the drug during the clinical trial.

Serious adverse reaction to the drug implies any unfavorable medical event which results in death, endangering life, hospitalization of the patient or prolongation of stay in hospital or the one which causes permanent dysfunction or disability.

Adverse event is medical occurrence temporally associated with the use of a medicinal product, but not necessarily causally related. Adverse experience is any unmanaged or unwanted sign, symptom or disease, which has time relationship with drug usage.

ADRs can be expected or unexpected. Expected adverse reaction is the reaction which had been previously discovered and described in Summary of Product characteristics. Unexpected adverse reaction is the reac- tion to the drug whose nature, severity or outcome has never been described in Summary of Product characteristics.

According to frequency, ADRs can be very common (>10\%), common (1-10\%), uncommon (0.1-1\%), rare (0.01-0.1\%), very rare $(<0.01 \%)$.

According to mechanism of origin, ADRs are classified in four types. Type A, dosedependent ADR with clear time relationship to drug intake, which are often discovered during the clinical trial and symptoms disappear after cessation of therapy. Type B or dose-independent $\mathrm{ADR}$, are rare $(0.01-0.1 \%)$ according to frequency. They are unexpected, and it is hard to establish causal-consequential relationship and mechanism. There is time relationship between using the drug and appearance of the adverse effect. These reactions are often allergic, pseudo allergic or idiosyncratic reaction or congenital enzymatic defect - they are individual, and they depend on patient's characteristics; usually they are not discovered during the clinical trials, but they are discovered after the appearance of the drug in the market, so that is why they can cause death. Type $\mathrm{C}$ represent higher frequency of 'spontaneous diseases' in population. Usually there is long latent period between the beginning of using the drug and manifestation of ADR. Time relationship between using the drug and the adverse reaction is less clear but mechanism is hard to establish [2]. Type D represent delayed ADR (e.g. cancer genesis, teratogenesis) [3].

It has been estimated that such ADRs are the 4th to 6th largest cause for mortality in the USA. They result in the death of several thousands of patients each year, and many more suffer from ADRs [4].

\section{Pharmacovigilance}

Pharmacovigilance is the science and activities relating to the detection, assessment, understanding and prevention of adverse effects or any other possible drug-related problems. Re- 
cently, its concerns have been widened to include herbals, traditional and complementary medicines, blood products, biologicals, medical devices, vaccines [5].

The history of pharmacovigilance goes back more than 50 years [6]. The beginning of the development of pharmacovigilance is linked to 'thalidomide catastrophe'. In early 1960s, thalidomide was the drug which was prescribed to pregnant women so that they can fall asleep easier and in order to reduce nausea. However, thalidomide caused between $10.000-15.000$ cases of severe deformation of the limbs (phocomelia) to the children whose mothers were using this drug [7]. In 1965 the eighteenth World Health Assembly, WHA 18.42, drew attention to the problem of ADR monitoring and following further resolutions in 1966, 1967 and 1970 the International Drug Monitoring Programme came into being [6].

By 2016, 123 countries have joined the programme [8]. The programme functions on the basis of national pharmacovigilance centers coordinated by the WHO Programme for International Drug Monitoring which consists of the WHO Collaborating Centre for International Drug Monitoring, Uppsala and the Pharmacovigilance Department of WHO, Geneva.

Therefore, it is essential that new and medically still evolving treatments are monitored for their effectiveness and safety under real-life conditions post release. Experience has shown that many ADRs, interactions (i.e. with foods or other medicines) and risk factors come to light only during the years after the release of a medicine [9].

The success or failure of any pharmacovigilance activity depends on the reporting of suspected ADR. To date, the mainstay of pharmacovigilance has been spontaneous reporting by health professionals. To detect the full spectrum of complications from pharmaceutical treatment and to gain a representative picture, all sectors of the health-care system need to be involved. This includes public and private hospitals, general practice, pharmacies, nursing homes, retail dispensaries and providers of traditional medicine. Wherever medicines are being used, there should be a readiness to observe and report unwanted and unexpected medical events. Reports made by a health professional are an interpretation of information originally provided by a patient who has experienced the actual benefit or harm of a medicine taken $[6,10]$.

A pharmacist contributes to drug safety by preventing, identification, documenting or reporting ADRs. The role of the pharmacist in pharmacovigilance system is different in countries. Nowadays the pharmacist also frequently acts as a consultant on pharmacotherapy and in the UK and USA pharmacists are, to a degree, also authorized to write out prescriptions, which, incidentally, has been a long-standing practice in many countries where doctors are in short supply. Currently the role of the pharmacist in the reporting of ADRs is not appreciated everywhere. In the Scandinavian countries, for instance, pharmacists are not authorized to report ADRs and in the United Kingdom they have only recently been allowed to report independently. By contrast, in the Netherlands $40 \%$ of the reports on ADRs are submitted by pharmacists [11].

An important clinical responsibility of the pharmacist is in the early detection of ADRs and other drug-related problems as well as monitoring the effectiveness of medicines. The pharmacist, as a part of the healthcare team, is a source of both information and critical evaluation of drug information. The pharmacist's expertise is vital to the application of the safety profile of a medicine to the needs of a particular patient [12].

\section{Reporting of ADRs in Serbia}

In Serbia, every medical worker is obligated to report an adverse reaction on the drug. Medicines and Medical Devices Agency of Serbia (ALIMS) and Nacional Pharmacovigilance Center (NPC) which works under this Agency are competent to follow and regulate reported adverse effect on drugs.

Reporting ADRs in Serbia is being done by filling in the form which is publicly available on site of ALIMS. After filling it, the form is being forwarded to ALIMS and NPC.

After the evaluation of collected data and identification of new safety findings, ALIMS takes steps to ensure that the medicine is used in a manner which minimizes risks and maximizes the benefits. These actions usually include changes to safety information in the Summary of Product Characteristics and Patient Information Leaflet In terms of adding new important warnings and precautions, and ADR, new contraindications, reduction of the recommended dose, limitations in the adminis- 
tration of a medicine. Other regulatory actions are also taken for risk management purposes, particularly in terms of risk minimization, and in rare cases, the decision can be made on termination of a marketing authorization, or to temporarily revoke a marketing authorization for safety reasons and to withdraw a medicine from the market, when it is demonstrated that the potential risk is greater than the expected benefit in normal therapeutic administration of a medicine [1]

According to information about number of reported ADRs which ALIMS had collected in period from 2005. - 2011. there is a steady rising trend in reporting ADRs. Total number of reports in 2011. was 962, or it was 128 reports per 1 million of residents in Serbia, and that number is still much smaller than 200 reports per 1 million of residents, which is expected number of reported ADRs according to advices, from World Health Organization (WHO), in order to achieve well developed national pharmacovigilance system. That means that Serbia needs 1400 ADRs per year. In 2015, NPC and ALIMS recorded 1170 reports. Number of reported reactions in 2015. was 15\% bigger than in 2014 [13].

During 2017, there were 964 reported ADRs, and that number is $12.76 \%$ smaller than in 2016.
Even though the number of reported ADRs from patients was $86.6 \%$ bigger than number in 2016, amount of reports is still small, and according to that we can conclude that system of reporting ADRs by patients in Serbia is not developed enough [14].

\section{AIM}

The aim of this research is that by collecting information about unexpected and ADRs, based on direct contact of pharmacists and patients, improve the role of a pharmacist in pharmacovigilance system.

\section{SUBJECTS AND METHODS}

Information about ADR were being collected in three private pharmacies in Indija and one private pharmacy in Sombor.

In period from 20.12.2017.-10.01.2018. pharmacists were recording ADRs.

In period from 11.01.2018.-01.02 .2018 . patients were additionally informed about ADRs.

Information was presented to patients in written forms and through them patients were informed about the importance of reporting unexpected and ADR. They were in-
Table 1. Categories and criteria for estimating causal-consequential relationship between ADR and used drug according to WHO

\section{Causality term Assessment criteria}

- Event or laboratory test abnormality, with plausible time relationship to drug intake

- Cannot be explained by disease or other drugs

- Response to withdrawal plausible (pharmacologically, pathologically)

- Event definitive pharmacologically or phenomenologically (i.e. an objective and specific medical disorder or a recognised pharmacological phenomenon)

- Rechallenge satisfactory, if necessary

\begin{tabular}{|c|c|}
\hline Probable/Likely & $\begin{array}{l}\text { - Event or laboratory test abnormality, with reasonable time relationship to } \\
\text { drug intake } \\
\text { - Unlikely to be attributed to disease or other drugs } \\
\text { - Response to withdrawal clinically reasonable } \\
\text { - Rechallenge not required }\end{array}$ \\
\hline Possible & $\begin{array}{l}\text { - Event or laboratory test abnormality, with reasonable time relationship to } \\
\text { drug intake } \\
\text { - Could also be explained by disease or other drugs } \\
\text { - Information on drug withdrawal may be lacking or unclear }\end{array}$ \\
\hline Unlikely & $\begin{array}{l}\text { - Event or laboratory test abnormality, with a time to drug intake that } \\
\text { makes a relationship improbable (but not impossible) } \\
\text { - Disease or other drugs provide plausible explanations }\end{array}$ \\
\hline Unclassified & $\begin{array}{l}\text { - Event or laboratory test abnormality } \\
\text { - More data for proper assessment needed, or } \\
\text { - Additional data under examination }\end{array}$ \\
\hline Unclassifiable & $\begin{array}{l}\text { - Report suggesting an adverse reaction } \\
\text { - Cannot be judged because information is insufficient or contradictory } \\
\text { - Data cannot be supplemented or verified }\end{array}$ \\
\hline
\end{tabular}


formed that during the report data about them would be anonymous and that the survey was being held in purpose of making a scientific work. It was written in text that if they had experienced any kind of adverse reaction they can report it to the phone number (author's phone number) or they can report it directly to the pharmacist in the pharmacy (Annex 1).

Needed information to fill in the form was about gender and age of the patient, description, result and duration of the adverse reaction, name, form and dose of the drug which lead to the adverse reaction, dosage regimen, method of application, indication and total usage time. Also, patients were asked if they had used some other drugs at the same time, and about some other relevant conditions in order to connect the adverse reaction to the suspect drug.

According to given information, forms available on site were filled and then sent to NPC.

NPC assessed reported ADRs in terms of expectation, seriousness and causalconsequential relationship between usage of the drug and the adverse effect.

For estimation of causal-consequential relationship NPC was using the World Health Organization's (WHO) methodology (Table 1) [15].

Suspect drugs are classified in categories according to ATC classification [16]:

- Group A - Alimentary tract and metabolism;

- Group B - Blood and blood forming organs;

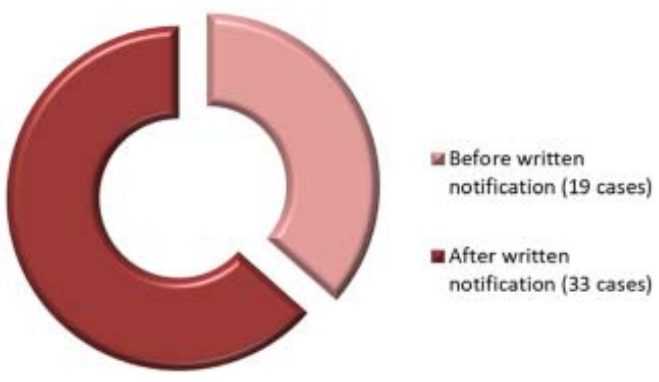

Figure 1. Contribution of collected ADRs before and after additional notification in regard to the number of all collected reports
- Group C - Cardiovascular system;

- Group D - Dermatologicals;

- Group G - Genito-urinary system and sex hormones;

- Group H - Systemic hormonal preparations, excluding sex hormones and insulins;

- Group J - Antiinfectives for systemic use;

- Group L - Antineoplastic and immunomodulating agents;

- Group M - Musculo-skeletal system;

- Group N - Nervous system;

- Group P - Antiparasitic products, insecti-

cides and repellents;

- Group R - Respiratory system;

- Group S - Sensory organs;

- Group V - Various.

\section{RESULTS}

In order to get the information about unexpected and adverse reactions to drugs, three private pharmacies in Inđija and one private pharmacy in Sombor were contacted in this survey.

In first period, from 20.12.2017. un-

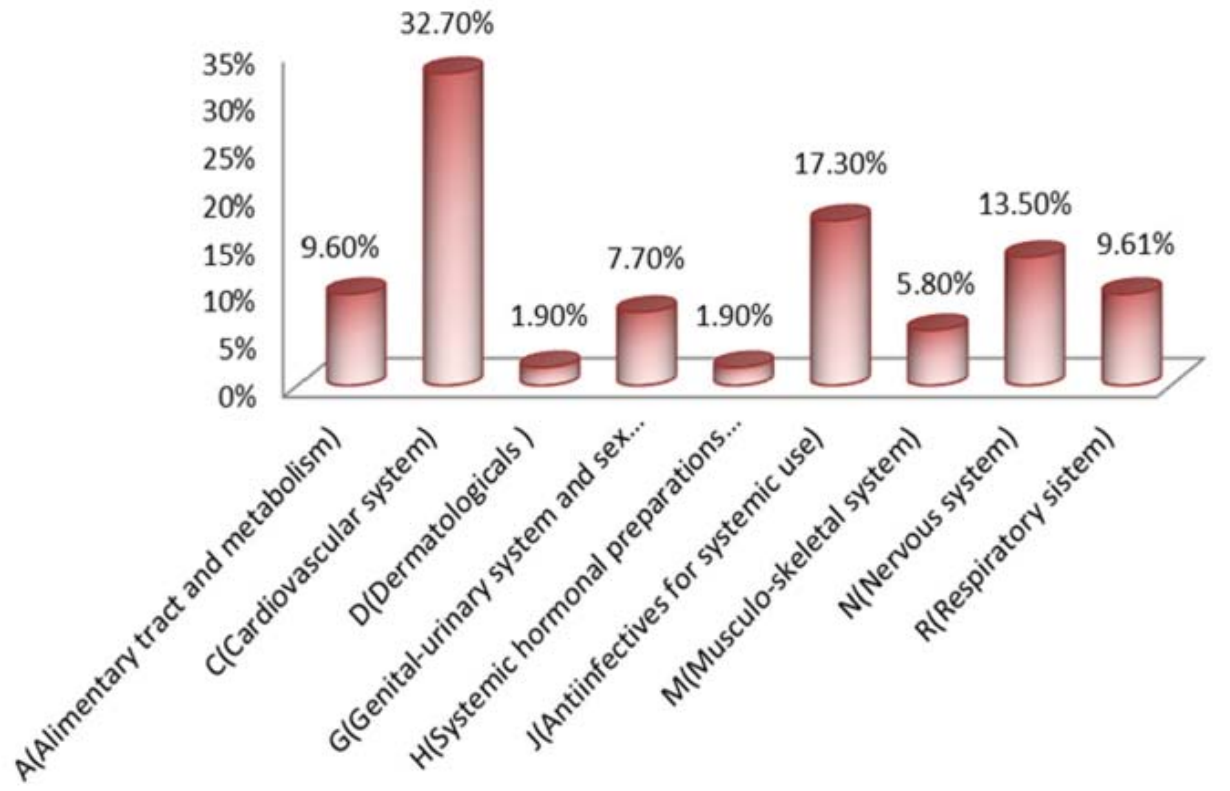

Figure 2. Percentage of suspected drugs classified according to ATC classification 
til 10.01.2018., there were 19 reported ADRs. After that, when patients were additionally informed about the importance of reporting adverse reactions to the drugs, in period from 11.01.2018. until 01.02.2018., there were 33 reported cases (Figure 1). Exactly 21 patients $(\approx 64 \%)$ reported their adverse reactions to the pharmacist, and $11(\approx 36 \%)$ patients reported it to the author.

Suspect drugs were classified by ATC classification, and their percentage share is shown in Figure 2.

The most of the reports of ADRs refer to drugs from group C according to ATC classification $(32.7 \%)$. Those drugs are used to treat cardiovascular diseases. Significant number of ADRs are caused both by anti-infectives for systemic use, which belong to group J $(15.4 \%)$ and drugs which are used for treating diseases of nervous system and which belong to group $\mathrm{N}$ (13.5\%).

According to NPC, all of the reported reactions are expected, which means that they are related to their mechanism of action or that they had been already described in Summary of Drug Characteristics. 3 out of 52 reported reactions were classified as serious. After estimating, it is concluded that causal-consequential relationship between ADR and used drug for drugs which caused serious ADRs is possible.

Drugs and adverse reactions which appeared after using them are classified according to ATC classification and shown in tables.

According to the collected information, five drugs which belong to group A (9.6\%), according to the ATC classification caused ADRs. Three patients had diarrhea and cramps after using metformin chloride, while one patient had a problem with constipation after using granisetron, and one patient was tired and drowsy after using metoclopramide (Table 2).

According to the collected information, majority of reported ADRs referred to drugs which are from group C (32.7\%), according to ATC classification, where belong drugs which are used in treating cardiovascular diseases. Seventeen drugs from this group
Table 2. Group A according to ATC classification

\begin{tabular}{|c|c|c|c|}
\hline GROUP OF DRUGS & DRUG & ADVERSE REACTION & $\begin{array}{l}\text { NUMBER OF } \\
\text { CASES }\end{array}$ \\
\hline biguanides & metformin chloride & diarrhea, cramps & 3 \\
\hline $\begin{array}{l}\text { serotonin antagonists with very } \\
\text { strong antiemetic effect }\end{array}$ & granisetron & constipation & 1 \\
\hline propulsives & metoclopramide & tiredness, drowsiness & 1 \\
\hline TOTAL & & & 5 \\
\hline
\end{tabular}

Table 3. Group $C$ according to ATC classification

\begin{tabular}{|c|c|c|c|}
\hline GROUP OF DRUGS & DRUG & ADVERSE REACTION & $\begin{array}{l}\text { NUMBER OF } \\
\text { CASES }\end{array}$ \\
\hline aldosterone antagonists & spironolactone & $\begin{array}{l}\text { hyperkalemia, cardiac } \\
\text { disorder }\end{array}$ & 1 \\
\hline organic nitrates & glyceryl trinitrate & strong headache & 2 \\
\hline \multirow{4}{*}{$\begin{array}{l}\text { selective calcium channel } \\
\text { blockers with predominant } \\
\text { vascular }\end{array}$} & amlodipine & hock edema, redness & 3 \\
\hline & nifedipine & hock edema, redness & 1 \\
\hline & felodipine & hock and knee edema & 1 \\
\hline & lercanidipine & redness & 1 \\
\hline $\begin{array}{l}\text { non-selective blockers of beta } \\
\text { adrenergic receptors }\end{array}$ & propranolol & $\begin{array}{l}\text { dry eyes, cold limbs, } \\
\text { insomnia }\end{array}$ & 2 \\
\hline \multirow{2}{*}{$\begin{array}{l}\text { selective blockers of } \\
\text { beta adrenergic receptors }\end{array}$} & metoprolol & dry cough, nightmare & 1 \\
\hline & bisoprolol & dry cough, impotence & 1 \\
\hline \multirow{3}{*}{$\begin{array}{l}\text { angiotensin converting } \\
\text { enzyme inhibitors, } \\
\text { monocomponent }\end{array}$} & enalapril & dry stimulant cough & 1 \\
\hline & ramipril & dry stimulant cough & 1 \\
\hline & fosinopril & dry stimulant cough & 1 \\
\hline $\begin{array}{l}\text { angiotensin converting } \\
\text { enzyme inhibitors, combination } \\
\text { with diuretics }\end{array}$ & $\begin{array}{l}\text { ramipril, } \\
\text { hydrochlorothiazide }\end{array}$ & dry stimulant cough & 1 \\
\hline TOTAL & & & 17 \\
\hline
\end{tabular}




\begin{tabular}{|c|c|c|c|}
\hline GROUP OF DRUGS & DRUG & ADVERSE REACTION & $\begin{array}{l}\text { NUMBER OF } \\
\text { CASES }\end{array}$ \\
\hline $\begin{array}{l}\text { anti-acne preparations for } \\
\text { systemic use }\end{array}$ & isotretinoin & dry mouth and eyes & 1 \\
\hline TOTAL & & & 1 \\
\hline
\end{tabular}

caused different ADRs. Amlodipine, one of calcium channel blockers, caused redness and hock edema to three patients. Same ADRs appeared to patients who used nifedipine, felodipine, lercanidipine. Two patients reported that after using glyceryl trinitrate beside significant decrease of blood pressure they felt strong headache. After using propranolol, nonselective blocker of beta adrenergic receptors, one patient had insomnia and feeling of cold limbs, while another patient had problem with eye dryness. Metoprolol, selective blocker of beta 1 adrenergic receptors, caused dry cough and nightmares in one case, while bisoprolol, drug from same group of drugs, caused dry cough and impotence. One patient noticed strong palpitations after using spironolactone, aldosterone antagonist. Angiotensin converting enzyme inhibitors, either as monocomponent therapy or in combination with diuretics caused dry stimulant cough (Table 3 ).
According to the collected information, only one drug from group $\mathrm{D}(1.9 \%)$, according to ATC classification, where belong the drugs used in treating skin diseases. This particular drug, isotretinoin, which is used for treating acnes, caused the feeling of dry mouth and eyes (Table 4).

According to the collected information, three drugs from group G (7.7\%), according to ATC classification, where belong drugs used in treating diseases of genito-urinary system caused ADRs. Two patients had orthostatic hypotension after using tamsulosine. One patient felt mood disorder after using drug which is consisted of cyproterone and estradiole, while one patient after using finasteride had problem with impotence (Table 5).

According to the information, one drug which from group $\mathrm{H}$ (1.9\%), according to ATC classification, where belong systemic hormonal preparations, caused ADR to one

\begin{tabular}{|c|c|c|c|}
\hline GROUP OF DRUGS & DRUG & ADVERSE REACTION & $\begin{array}{l}\text { NUMBER OF } \\
\text { CASES }\end{array}$ \\
\hline anti androgen and estrogens & $\begin{array}{l}\text { cyproterone, } \\
\text { estradiole }\end{array}$ & $\begin{array}{l}\text { mood disorder, } \\
\text { depression }\end{array}$ & 1 \\
\hline $\begin{array}{l}\text { alpha adrenergic receptors } \\
\text { antagonists }\end{array}$ & tamsulosine & orthostatic hypotension & 2 \\
\hline $\begin{array}{l}\text { testosterone } 5 \text { alpha reductase } \\
\text { inhibitors }\end{array}$ & finasteride & impotence & 1 \\
\hline TOTAL & & & 4 \\
\hline
\end{tabular}

\begin{tabular}{|c|c|c|c|}
\hline GROUP OF DRUGS & DRUG & ADVERSE REACTION & $\begin{array}{l}\text { NUMBER OF } \\
\text { CASES }\end{array}$ \\
\hline corticosteroids for systemic use & dexamethasone & weight gain & 1 \\
\hline TOTAL & & & 1 \\
\hline GROUP OF DRUGS & DRUG & ADVERSE REACTION & $\begin{array}{l}\text { NUMBER OF } \\
\text { CASES }\end{array}$ \\
\hline cephalosporins, $1^{\text {st }}$ generation & cephalexin & nausea, vomiting & 2 \\
\hline macrolides & erythromycin & rash on the hands & 1 \\
\hline $\begin{array}{l}\text { natural penicillins sensitive to } \\
\text { beta-lactamase }\end{array}$ & benzylpenicillin & hypersensitivity reaction & 2 \\
\hline tetracyclines & $\begin{array}{l}\text { doxycycline } \\
\text { tetracycline }\end{array}$ & $\begin{array}{l}\text { photosensitivity reaction } \\
\text { nausea, diarrhea }\end{array}$ & $\begin{array}{l}1 \\
2\end{array}$ \\
\hline nitroimidazole derivatives & metronidazole & $\begin{array}{l}\text { nausea, metallic taste in } \\
\text { the mouth }\end{array}$ & 1 \\
\hline TOTAL & & & 9 \\
\hline
\end{tabular}

Table 5. Group G according to ATC classification

Table 4. Group D according to ATC classification
Table 6. Group H according to ATC classification
Table 7. Group J according to ATC classification 
Table 8. Group $M$ according to ATC classification

\begin{tabular}{l}
\multicolumn{1}{c|}{ GROUP OF DRUGS } \\
inhibitor of uric acid synthesis \\
oxicams \\
other non-steroidal \\
antiinflammatory drugs
\end{tabular}

DRUG
allopurinol
meloxicam
glucosamine

TOTAL

patient. Using of dexamethasone caused gaining weight to one patient (Table 6).

According to the information, nine drugs from group $J(17.3 \%)$, according to ATC classification, where belong anti-infective drugs for systemic use, caused ADRs. Two patients had gastrointestinal problems, nausea and vomiting, after using cephalexin. Erythromycin caused rash on the hands to the one patient. Two patients had hypersensitivity reactions after intramuscular application of procain benzylpenicillin. Tetracyclines for systemic use, caused two ADRs. Doxycycline caused photosensitivity reaction, while tetracycline caused nausea and diarrhea. One patient had nausea and metallic taste in the mouth after using metronidazole (Table 7).

According to information, three drugs from group $\mathrm{M}(5.8 \%)$, according to ATC classification, where belong the drugs used for treatment of mucsulo-skeletal system diseases, caused ADRs. Using allopurinol caused in- creased blood pressure to one patient. Nausea and vomiting were reactions that happened after one patient used meloxicam, while glucosamine caused abdominal pain and nausea to the one patient (Table 8).

According to the collected information, six drugs from group $\mathrm{N}$ (13.5\%), according to ATC classification, where belong drugs used for treating diseases of central nervous system, caused ADRs. One patient had rash on the hands after using metamizol. Acetylsalicylic acid caused dyspepsia to two patients. One patient had hot flashes after using vinpocetine. Antiepileptic drugs, topiramate and carbamazepine, caused visual disorders, diplopia and nystagmus. One patient noticed that he had gained weight while using amitriptyline (Table 9).

According to the collected information, five drugs from group R (9.6\%), according to ATC classification, where belong drugs for treating diseases of respiratory system,
Table 9. Group $\mathrm{N}$ according to ATC classification

\begin{tabular}{|c|c|c|c|}
\hline GROUP OF DRUGS & DRUG & ADVERSE REACTION & $\begin{array}{l}\text { NUMBER OF } \\
\text { CASES }\end{array}$ \\
\hline pyrazolones & metamizol & rash on the hands & 1 \\
\hline $\begin{array}{l}\text { other analgetics, antipyretics, } \\
\text { salicylic acid and derivatives }\end{array}$ & acetylsalicylic acid & dyspepsia & 2 \\
\hline $\begin{array}{l}\text { other psychostimulants and } \\
\text { nootropics }\end{array}$ & vinpocetine & hot flashes & 1 \\
\hline $\begin{array}{l}\text { antiepileptics, carboxamide } \\
\text { derivatives }\end{array}$ & carbamazepine & diplopia, nystagmus & 1 \\
\hline other antiepileptics & topiramate & visual disorder, diplopia & 1 \\
\hline $\begin{array}{l}\text { non-selective monoamine } \\
\text { reuptake inhibitors }\end{array}$ & amitriptyline & weight gain & 1 \\
\hline TOTAL & & & 7 \\
\hline
\end{tabular}

Table 10. Group R according to ATC classification

$\quad$ GROUP OF DRUGS
mucolytics
other antihistamines with
systemic use
leukotriene receptor antago-
nists
selective beta-2-adrenoceptor
agonists

\begin{tabular}{|l|l|c|}
\hline \multicolumn{1}{|c|}{ DRUG } & \multicolumn{1}{|c|}{ ADVERSE REACTION } & $\begin{array}{c}\text { NUMBER OF } \\
\text { CASES }\end{array}$ \\
\hline acetylcysteine & bronchospasm & 1 \\
\hline desloratadine & epileptic seizure & 1 \\
\hline montelukast & tremor in hands & 1 \\
\hline salbutamol & anxiety, tremor in hands & 2 \\
\hline
\end{tabular}


caused ADRs. Acetylcysteine caused bronchospasm to the one patient. One patient, who has epilepsy, after using desloratadine had generalized contractions of skeletal muscles, which were identic to generalized epileptic seizure. Using of montelukast caused tremor in hands to the one patient. Two patients reported anxiety and tremor in hands after using salbutamol (Table 10).

\section{DISCUSSION}

The success of pharmacovigilance system in Serbia depends on spontaneous reports of ADRs. In Serbia, number of spontaneous reports is getting bigger every year, which is proven by the data that number of reported ADRs in 2003 was 70, but in 2015. there were 1170 reported ADRs. According to the information about reported ADRs in 2015, 101 referred to vaccines, 993 referred to the other drugs. The largest number of ADRs were reported by license holders (553), then from health workers (526). From patients there were only 18 reported ADRs. The majority of reported ADRs by health workers were from doctors. Partition of pharmacists in reporting ADRs is growing every year, but still is not enough, compared to doctors [13, 17].

The risk of harm, however, is less when medicines are used by an informed health professionals and by patients who themselves understand and share responsibility for their drugs. When adverse effects and toxicity appear - particularly when previously unknown in association with the medicine - it is essential that they should be analyzed and communicated effectively to an audience that has the knowledge to interpret the information. Therefore. we can conclude that the role of pharmacovigilance is firstly managing the risk of $\mathrm{ADR}$ in order to avoid their serious consequences $[5,18]$.

In this research, there were total of 52 collected ADRs by active collecting in contact with pharmacists. In first period, which lasted 21 days, pharmacists in all four pharmacies were collecting reports of ADRs. At the end of this period, there were 19 collected reports.

During the second period, which also lasted 21 days, pharmacists in collaboration with authors were informing patients about the importance of reporting ADRs through written form (Annex 1). After this additional information, number of reported ADRs in- creased. There were 33 reported ADRs, at the end of this period. That means that the number was increased almost twice. Thanks to this information, it can be concluded that additional information is really important in process of improving system of reporting ADRs, and also for upgrading the relationship between patients and pharmacists. After the information, patients who were reporting ADRs were asking for an advice how to use that suspect drug further on.

Forms for reporting ADRs, were filled based on the collected reports and then sent to NPC. Later, NPC was analyzing reported ADRs and sending back the information to the authors, about reaction, if it was expected or unexpected, how serious it was and if there was causal-consequential relationship between ADR and used drug.

The largest number of reports refers to the drugs from group C (ATC classification) (32.7\%), where belong drugs which are used in treating cardiovascular diseases, which was expected considering the fact of incidence of cardiovascular diseases nowadays in our surrounding. Selective calcium channels blockers, amlodipine and nifedipine, caused hock edema and redness several times. These adverse reactions are frequent, expected and don't meet the criteria of seriousness. Angiotensin converting enzyme inhibitors caused in several cases dry stimulant cough, which is characteristic for this group of drugs, so it was expected, doesn't meet the criteria of seriousness and it is also listed in summary of drug characteristics. Selective blockers of beta adrenergic receptors also caused reactions such as cold limbs, nightmares, insomnia, dry cough, but neither of them meets the criteria of seriousness.

The second place according to number of reported ADRs belongs to drugs from group J (ATC classification), where belong antiinfective drugs (15.4\%). Majority of these reports were also expected, considering the fact that those drugs are often used by patients without previous consulting with doctors. Problems with gastrointestinal system, such as nausea, vomiting and diarrhea are most common reactions and they don't meet the criteria of seriousness. Hypersensitivity reactions are also reactions which occurred after using drugs from this group, and they meet criteria of seriousness.

Drugs from group N (ATC classification) according to number of reported ADRs 
are on third place in this research (13.5\%). Considering the fact that cyclooxygenase type 1 takes part in synthesis of gastro protective prostaglandins, deficiency of this enzyme causes different gastrointestinal problems. In that manner, we can explain that acetylsalicylic acid, as non-selective cyclooxygenase type 1 and 2 inhibitor, causes gastric pain which is expected ADR and doesn't meet the criteria of seriousness [19]. Visual disorder, diplopia, nystagmus are characteristic adverse reactions caused by antiepileptic drugs, so these reported reactions are expected and don't meet the criteria of seriousness [20].

NPC estimated that all of reported ADRs were expected, based on the information from summary of drug characteristics, relevant medical literature and criteria for estimating of seriousness of ADR. From total of 52 reported reactions, 49 of them don't meet the criteria of seriousness. The rate of reporting of these adverse reactions after using these drugs is in accordance with the frequency of reporting, and the safety profiles of these drugs remain unchanged [1]. However, 3 reports were classified as serious adverse reactions. Two of them were hypersensitive reactions, which were caused by usage od procaine-benzylpenicillin and benzylpenicillin. The third serious reaction was an epileptic seizure which was caused by usage of desloratadine.

In both cases, anaphylactic shock happened after intramuscular usage of procainebenzylpenicillin. Reaction appeared soon after administration of the drug. It started with erythema, pruritus, and then bronchospasm and hypotensive shock, after which patients were given the proper therapy.

Penicillin antibiotics are the drugs most frequently suspected in drug hypersensitivity reactions. Drug allergies are divided into immediate and delayed reactions with different immunological mechanisms. Immediate reactions occur less than 1 hour after drug administration and clinical presentation varies from urticaria to life-threatening anaphylactic shock. The most common delayed reactions are maculopapular exanthema and delayedonset urticaria, which are non-severe and self-limiting diseases. Severe delayed reactions such as acute generalized pustulosis, StevensJohnson syndrome or toxic epidermal necrolysis are rare and are accompanied by danger signs such as fever, bullous lesions, and mucosal and other organ involvement [21].
In both reported cases appeared immediate reaction to intramuscular administration of procaine-benzylpenicillin.

Some clinical experiences indicate that H1-antihistamines, especially first-generation H1-antagonists, which pass the blood brain barrier, occasionally provoke convulsions in healthy children as well as epileptic patients. Even though CNS ADRs are rare after using non-sedating $\mathrm{H} 1$ antihistamines, there are several noted cases when they caused epileptic seizures [22].

Safer use of modern and traditional medicines is an ambitious goal of pharmacovigilance. It depends on patients and health professionals, health ministries, regulators, and manufacturers working actively together. The priority of pharmacovigilance is to identify when patients suffer any kind of harm from their therapy and to reduce the risk of this happening in the future.

In our study, direct communication with pharmacists and additional informing of patients about the importance of reporting of ADRs, significantly increased the participation of pharmacists in the total number of collected ADRs and their role in pharmacovigilance system in our country.

\section{CONCLUSION}

Even though reporting ADRs is duty for all the health professionals, in Serbia, number of spontaneous ADRs is still not enough for establishment a developed national pharmacovigilance system, in accordance with recommendations of WHO.

In this study, an active collecting of ADRs and additional informing of patients about the importance of reporting of ADRs, significantly contribute to improve the pharmacovigilance system and the safety of pharmacotherapy in our country.

\section{ACKNOWLEDGEMENT}

This research was supported by the Ministry of Education, Science and Technological Development, Republic of Serbia, Project No 41012.

\section{CONFLICT OF INTEREST}

The authors have no conflicts of interest that are directly relevant to the content of this study. 


\section{REFERENCES}

1. Alims.gov.rs [homepage on the internet]. Beograd, Srbija: Agencija za lekove I medicinska sredstva Srbije. 2018. Available from: https://www.alims.gov. rs/ciril/farmakovigilanca/.

2. Prostran M, Stanulović M, Marisavljević D, Đurić D. Farmaceutska medicina. 1. izdanje. Vršac: Hemofarm a.d.; 2009.

3. Goločorbin Kon S, Mikov M. Odabrana poglavlja iz kliničke farmacije. Novi Sad: Ortomedics; 2010.

4. Who.int [homepageontheinternet].Geneva:World Health Organisation. 2002. Available from: http:// apps.who.int/iris/bitstream/10665/67378/1/ WHO_EDM_QSM_2002.2.pdf

5. Who.int [homepage on the internet]. United Kingdom: World Health Organisation. 2002. Available from: http://apps.who.int/medicinedocs/ $\mathrm{pdf} / \mathrm{s} 4893 \mathrm{e} / \mathrm{s} 4893 \mathrm{e} . \mathrm{pdf}$ ?ua $=1$.

6. Who.int [homepage on the internet]. France: World Health Organisation. 2006. Available from: http: / / www. who.int/medicines/areas/quality_safety/safety_efficacy/Pharmacovigilance_B. pdf?ua=1.

7. Alims.gov.rs [homepage on the internet]. Beograd, Srbija: Agencija za lekove I medicinska sredstva Srbije. 2014. Available from: https://www.alims.gov. rs/ciril/files/2014/10/Brosura-za-ZR.pdf.

8. Who.int [homepage on the internet]. Geneva: World Health Organisation. 2018. Available from: http: / / www. who.int/medicines/areas/quality safety/safety_efficacy/National_PV_Centres_Map/ en/.

9. Who.int [homepage on the internet]. Geneva: World Health Organisation. 2004. Available from: http://apps.who.int/medicinedocs/pdf/s6164e/ s6164e.pdf.

10. Pal SN, Duncombe C, Falzon D, Olsson S. WHO Strategy for Collecting Safety Data in Public Health Programmes: Complementing Spontaneous Reporting Systems. Drug Saf 2013;36:75-81

11. Hussain R, Hassali MA, Hashmi F, Farooqui M. A qualitative exploration of knowledge, attitudes and practices of hospital pharmacists towards adverse drug reaction reporting system in Lahore, Pakistan. J Pharm Policy Pract. 2018;11:16.

12. Fip.org [homepage on the internet]. Hague, The Netherlands: International Pharmaceutical Federation. 2006. Available from: https://www.fip.org/ $w w w /$ uploads $/$ database_file.php?id=273\&table_id= .27

13. Alims.gov.rs [homepage on the internet]. Beograd: Agencija za lekove i medicinska sredstva Srbije. 2015. Available from: https://www.alims. gov.rs/ciril/files/2017/08/NDL2015.pdf.

14. Alims.gov.rs [homepage on the internet].
Beograd: Agencija za lekove i medicinska sredstva Srbije. 2017. Available from: https://www.alims. gov.rs/ciril/files/2018/07/NCF-2017.pdf

15. Who.int [homepage on the internet]. Uppsala: The Uppsala Monitoring Centre. Available from: http://www. who.int/medicines/areas/quality_ safety/safety_efficacy/WHOcausality_assessment. pdf.

16. Jakovljević V, Mikov M, Tomić Z. Lekovi u prometu: Priručnik o lekovima i njihovoj primeni. 19. izdanje. Novi Sad: Ortomedics; 2011.

17. van Grootheest K, Olsson S, Couper M, de Jongvan den Berg L. Pharmacists' role in reporting adverse drug reactions in an international perspective. Pharmacoepidemiol Drug Saf. 2004;13(7):457-64

18. Jeetu G, Anusha G. Pharmacovigilance: a worldwide master key for drug safety monitoring. J Young Pharm.2010;2(3):315-20

19. Shim YK1, Kim N. Nonsteroidal Anti-inflammatory Drug and Aspirin-induced Peptic Ulcer Disease. Korean J Gastroenterol. 2016;67(6):300-12.

20. Hilton EJ, Hosking SL, Betts T. The effect of antiepileptic drugs on visual performance. Seizure. 2004;13(2):113-28.

21. Kopac P, Zidarn M, Kosnik M. Epidemiology of hypersensitivity reactions to penicillin in Slovenia. Acta Dermatovenerol Alp Pannonica Adriat. 2012;21(4):65-7.

22. Cerminara C, El-Malhany N, Roberto D, Lo Castro A, Curatolo P. Seizures induced by desloratadine, a second-generation antihistamine: clinical observations. Neuropediatrics. 2013;44(4):222-4. 


\section{ANNEX 1}

\section{Measures for improving reporting adverse drug reactions}

Dear Sir/Madam,

Beside the effects of the drugs because of which they are prescribed to the patients, there are some other effects of drugs, which are sometimes good, but sometimes are not good (adverse drug effect/reaction).

Reporting of adverse drug reaction can lead to drug withdrawal from the market, different limitations in treatment, or chnging of drug indications.

By following and reporting changes which are suspected to be caused by using of the drug, we can lower the risk which is related to their usage, and at the same time we can see the benefits which are expected after using the drug.

Health professionals are reporting adverse drug reactions after they are reported to them by patients. Because of that, please be kind that if You had ever experienced such reaction after using any drug, report it to Your pharmacist or call phone number 063/8-261-529.

This research is part of scientific work of Marija Lučić, 4th year pharmacy student. Information collected in this research stay anonymus. Information will be sent to the central service for reporting adverse drug reactions in Belgrade.

Thank You for participating in this research! 


\title{
Uloga farmaceuta u sistemu prijavljivanja neželjnih reakcija na lekove
}

\author{
Marija M. Lučić ${ }^{1}$, Nastasija P. Milošević ${ }^{1}$, Nikola B. Martić ${ }^{1}$, Milica M. Paut Kusturica ${ }^{1}$, \\ Vojin M. Jovančević ${ }^{2}$, Milan B. Ubavićs , Nemanja B. Todorović ${ }^{4}$, Dejan J. Krajačić ${ }^{5}$, \\ Aleksandar L. Rašković ${ }^{1}$ \\ ${ }^{1}$ Katedra za farmakologiju i toksikologiju, Medicinski fakultet Novi Sad, Univerzitet u Novom Sadu, Novi \\ Sad, Srbija \\ ${ }^{2}$ Pokrajinski sekretarijat za obrazovanje, propise, upravu i nacionalne manjine - nacionalne zajednice, \\ Novi Sad, Srbija \\ ${ }^{3}$ Zavod za laboratorijsku dijagnostiku, Medlab, Novi Sad, Srbija \\ ${ }^{4}$ Katedra za farmaciju, Medicinski fakultet Novi Sad, Univerzitet u Novom Sadu, Novi Sad, Srbija \\ ${ }^{5}$ Opšta bolnica "Dr Radivoj Simonović" Sombor, Srbija
}

\section{KRATAK SADRŽAJ}

Uvod: lako predstavljaju značajnog posrednika između pacijenata i Nacionalnog centra za farmakovigilancu, farmaceuti još uvek ne učestvuju u dovoljnoj meri u sistemu prijavljivanja neželjenih reakcija na lekove (NRL). Prijavljivanjem NRL popravljaju se kvalitet terapije, kvalitet života pacijenata i podstiče se farmaceutska industrija za osmišljavanje i izradu novih formulacija koje će se bolje podnositi i čijom primenom će se značajno poboljšati odnos koristi i rizika farmakoterapije.

Cilj: Cilj rada je da prikupljanjem podataka o neočekivanim i neželjenim dejstvima lekova, direktnim kontaktom sa farmaceutima i pacijentima, poveća udeo farmaceuta u sistemu farmakovigilance u našoj zemlji.

Materijal i metode: Podaci o neželjenim delovanjima lekova prikupljeni su u apotekama u Somboru i Inđiji, popunjavanjem standardnog obrasca za prijavu NRL, preuzetog od strane Nacionalnog centra za farmakovigilancu (NCF). U periodu od 20.12.2017.10.01.2018 godine farmaceuti su beležili slučajeve NRL koji su prijavljeni od strane pacijenata. U periodu od 11.01.-01.02.2018. pacijenti su dodatno informisani o neželjenim i neočekivanim reakcijama na lekove. Popunjeni obrasci su poslati NCF u cilju procene očekivanosti, ozbiljnosti i uzročno-posledične povezanosti između NRL-a i primene leka.

Rezultati: U prvom periodu prikupljeno je 19 slučajeva NRL-a. Nakon toga, kada su pacijenti dodatno informisani o značaju prijavljivanja neželjenih i neočekivanih reakcija na lekove, prijavljeno je 33 slučaja NRL-a. Najveći broj prijavljenih neželjenih reakcija je bio iz grupe C lekova prema ATC klasifikaciji, odnosno lekova koji se koriste u terapiji kardiovaskularnih oboljenja (32,7\%), zatim iz grupe J lekova, odnosno antiinfektivnih lekova sa sistemskim delovanjem $(15,4 \%)$ i iz grupe $N$ lekova, odnosno lekova koji deluju na centralni nervni sistem (13,5\%). Nakon obrade prijavljenih NRL, prema NCF-u sve neželjene reakcije su očekivane (52), od čega 3 ispunjavaju kriterijume ozbiljnosti.

Zaključak: Direktnom komunikacijom sa farmaceutima i dodatnim informisanjem pacijenata o značaju prijavljivanja neželjenih reakcija na lekove povećava se uloga farmaceuta u sistemu farmakovigilance i poboljšava bezbednost farmakoterapije u našoj sredini.

Ključne reči: neočekivane i neželjene reakcije; farmakovigilanca 